\title{
Removal of Heavy Metals from Tannery Wastewater by using Sawdust and Spent Tea Leaves as an Adsorbent
}

\section{Abu Sayid Mia MD ${ }^{1,2 *}$, Uzzal Ali MD², Nur-E-Alam MD³ , Mafizur Rahman $\mathrm{MD}^{4}$ and Zahangir Alam $\mathrm{MD}^{2}$}

${ }^{1}$ Institute of Leather Engineering and Technology, University of Dhaka, Bangladesh

${ }^{2}$ Department of Applied Chemistry and Chemical Engineering, University of Dhaka, Bangladesh

${ }^{3}$ Leather Research Institute (LRI), Bangladesh Council of Scientific and Industrial Research (BCSIR), Bangladesh

${ }^{4}$ Department of Civil Engineering, Bangladesh University of Engineering and Technology (BUET), Bangladesh

*Corresponding author: Abu Sayid Mia MD, Institute of Leather Engineering and Technology, University of Dhaka, Dhaka 1209, Bangladesh, Tel: 01927907551; Email: emsayid@gmail.com

\section{Abstract}

Innovative processes for treating tannery wastewater containing heavy metals often involve technologies for reduction of toxicity in order to meet standards. Adsorbent is the most frequently studied and widely applied for the treatment of metalcontaminated wastewater. The removal of heavy metals e.g., chromium, nickel and lead from tannery wastewater at low concentrations is a recurring challenge, especially in developing countries. Batch studies were performed to evaluate the influences of various experimental parameters like adsorbent dose, contact time and $\mathrm{pH}$. The removal of dyes from effluent using adsorption process provides an attractive alternative treatment, especially if the adsorbant is inexpensive and readily available. In this study, the low-cost adsorbant spent tea leaves and saw dust were used for removal of heavy metals from waste effluent of leather tanning industry. The adsorbants were found to be capable of removing heavy metals from wastewater; the metals removal capacity for spent tea leaves was approximately $99 \%$ at optimum dose, contact time and $\mathrm{pH}$.

Keywords: Adsorption; Spent tea leaves; Saw dust; Tannery wastewater; Heavy metal

\section{Introduction}

Water is the most vital element among the natural resources and is crucial for the survival of all living organisms. The increasing urbanization and industrialization of Savar, Dhaka, have negative implications on water quality as well as other environmental issues [1]. The pollution from industrial and urban waste effluents and from agrochemicals in some water bodies and rivers has reached alarming levels. There are numerous ill effects of pollution, each type of pollutants having different effect, on human and animal health and ecology [2]. Chromium which largely used in tanning process, is one of the water pollutants which is a micronutrient required by our body in minute quantity. The form of trivalent chromium or Chromium-3 is safe [3]. Chromium also exists in another very rare form known as Hexavalent chromium or Chromium-6 [4]. This is usually introduced into ground water when chemical industries using chromium discharging wastewater without proper treatment [5]. Hexavalent chromium-6 is poisonous and should be removed from all kinds potable water. It causes cancer, anuria, nephritis, gastrointestinal ulceration, perforation in partition of nose. It penetrates cell membrane and badly affects central nervous system, causes respiratory trouble, and lung tumors when inhaled [7]. Trace amount of $\mathrm{Cr}$ (III) is essential for normal glucose, protein and fat 
metabolism and hence it is an essential trace element in diet [8-10]. Lead, nickel and chromium are often detected in industrial wastewaters, which originate from metal plating, mining activities, smelting, battery manufacture, tanneries, petroleum refining, paint manufacture, pesticides, pigment manufacture, printing and photographic industries, etc $[11,12]$. Unlike organic wastes, heavy metals are nonbiodegradable and they can be accumulated in living tissues, causing various diseases and disorders; therefore, they must be removed before discharge.

Chromium metal ions are usually removed by precipitation although ion exchange and adsorption are also used for its removal. The hydroxides of heavy metals are usually insoluble, so lime is commonly used for precipitating them. There are various methods to remove $\mathrm{Cr}$ including chemical precipitation, membrane process, ion exchange, liquid extraction and electrodialysis [13]. These methods are non-economical and have many disadvantages such as incomplete metal removal, high reagent and energy requirements, generation of toxic sludge or other waste products that require disposal or treatment [14]. In contrast, the adsorption technique is one of the preferred methods for removal of heavy metals because of its efficiency and low cost [15].

Utilizing the waste material from sawmills can make treatment process economical and solve the solid waste disposal problem. Although it has been invented many years ago, saw dust and activated carbon is still the most popular adsorbents throughout the world due to their high adsorptive capacity [16]. Sawdust or wood dust is a byproduct of cutting, grinding, drilling, sanding, or otherwise pulverizing wood or any other material with a saw or other tool; it is composed of fine particles of wood.

Tea is one of the most popular beverages and about 3.5 million tons of tea was consumed annually in the world [17]. The annual per capita consumption of tea in Bangladesh is $0.390 \mathrm{~kg}$ in 2013 [18]. After brewing, the spent tea becomes a waste which must be disposed of and that creates disposal problems. In present modern lifestyle, tea has become as essential drink due to improvement of people's living standard and that results in the disposal of spent tea leaves which has gradually become an unavoidable challenge [19].

The present study was aimed at selection of low-cost adsorbents from sawdust and spent tea leaves, which can adsorb heavy metals from the tannery effluent effectively.

\section{Materials and Methods}

\section{Sample Collection}

Tannery wastewater was collected from tannery estate,
Savar, Dhaka. Pre-washed plastic jars were used for sample collection.

\section{Preparation of Adsorbent}

Sawdust is solid waste product of sawmills. This sawdust was collected from sawmills of Don Chember, Narayanganj, Bangladesh. Sawdust was washed with water to remove dust, soil, silica and other contaminations. Then it was dried with sunlight and heated in oven to $105^{\circ} \mathrm{C}$ for 24 hours.

Spent tea leaves were collected from local tea stalls near University of Dhaka. It was used for the treatment as adsorbent. Surface impurities were removed from tea wastes by washing with boiling water. Color was also removed by repeating washing. The tea leaves were then oven dried for $6-8 \mathrm{~h}$ at $105^{\circ} \mathrm{C}$.

\section{Adsorbent Size}

Sieving machine (retsch D-42459 HAAN, Germany) was used to separate the sample into desired size. Adsorbent was separated into different mesh size (30 to less than 40 and $\geq 40$ ) by using sieving machine.

\section{Experimental Procedure}

In this study, the batch technique was performed in a series of beakers equipped with stirrers by stirring the tannery effluent. The batch technique was selected for its authenticity and simplicity [20]. After scheduled time, the suspension was filtered and the residual concentration of metal ions in the aqueous phase was measured by atomic absorption spectrophotometer (JEOL JSM-7600F). 250 $\mathrm{mL}$ of sample was conducted with varying adsorbent dose (1.5-17 g/L), contact time (30-150 min) and $\mathrm{pH}(4-10)$ at room temperature. Finally, Langmuir and Freundlich isotherms were also observed to determine the best model that characterizes the adsorption mechanism.

The physical parameters including total suspended solids (TSS), total dissolved solids (TDS), electrical conductivity (EC), $\mathrm{pH}$, biological oxygen demand $\left(\mathrm{BOD}_{5}\right)$, chemical oxygen demand (COD) of raw tannery effluent and treated effluent were measured. Chemical parameter like sulfate $\left(\mathrm{SO}^{2-}\right)$ and heavy metals such as $\mathrm{Cr}, \mathrm{Ni}$ and $\mathrm{Pb}$ of raw and treated effluents were analyzed. Colors were measured in Pt-Co color unit.

\section{Results and Discussion}

\section{Characterization}

The investigated physico-chemical characteristics of 
tannery effluents are shown in Table 1.

\begin{tabular}{|c|c|c|}
\hline Parameters & Raw Effluents & Standard Limits (ISI-2000/ISW-BDS) \\
\hline Colour units $\left(\mathrm{pt}-\mathrm{c}_{\mathrm{o}}\right)$ & 1640 & $6.0-9.0$ \\
\hline $\mathrm{pH}$ & 7.3 & 0.288 \\
\hline $\mathrm{EC}(\mathrm{mS} / \mathrm{cm})$ & 21.45 & 100 \\
\hline $\mathrm{TSS}(\mathrm{mg} / \mathrm{L})$ & 5500 & 2100 \\
\hline $\mathrm{TDS}(\mathrm{mg} / \mathrm{L})$ & 13000 & 2200 \\
\hline $\mathrm{TS}(\mathrm{mg} / \mathrm{L})$ & 18600 & $4.0-6.0$ \\
\hline $\mathrm{DO}(\mathrm{mg} / \mathrm{L})$ & 1.2 & $30 / 250$ \\
\hline $\mathrm{BOD}{ }_{5}(\mathrm{mg} / \mathrm{L})$ & 830 & $250 / 400$ \\
\hline $\mathrm{COD}(\mathrm{mg} / \mathrm{L})$ & 3790 & 1000 \\
\hline $\mathrm{SO}{ }_{4}{ }^{2-}(\mathrm{mg} / \mathrm{L})$ & 3850 & 02 \\
\hline $\mathrm{Cr}(\mathrm{mg} / \mathrm{L})$ & 25.60 & -- \\
\hline $\mathrm{Pb}(\mathrm{mg} / \mathrm{L})$ & 3.40 & -- \\
\hline $\mathrm{Ni}(\mathrm{mg} / \mathrm{L})$ & 1.35 & \\
\hline
\end{tabular}

Table 1: Characteristics of studied tannery effluent.

\section{Effect of Contact Time}

This study was conducted by agitating $250 \mathrm{~mL}$ sample for different time period 30-150 min. After the predetermined time intervals, the samples were filtered and then analyzed. Figure 1 shows that the sorption increased at $60 \mathrm{~min}$ and it became almost constant at $150 \mathrm{~min}$ for all metal ions. At the beginning the metal ions uptake was high since all active sites of adsorbent were vacant. After that, only a very low increase in the metal ions uptake was occurred as there were few surface-active sites left on the adsorbent. The quick equilibrium time is due to the small particle size as the effective surface area is high for small particles.

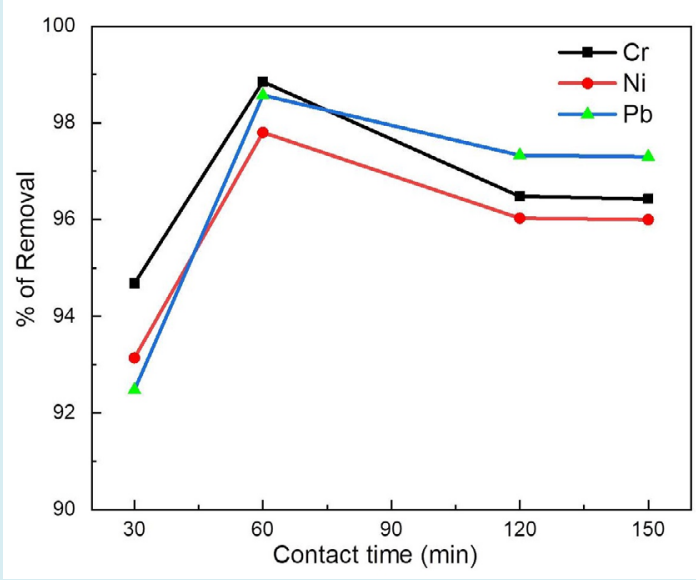

(a)

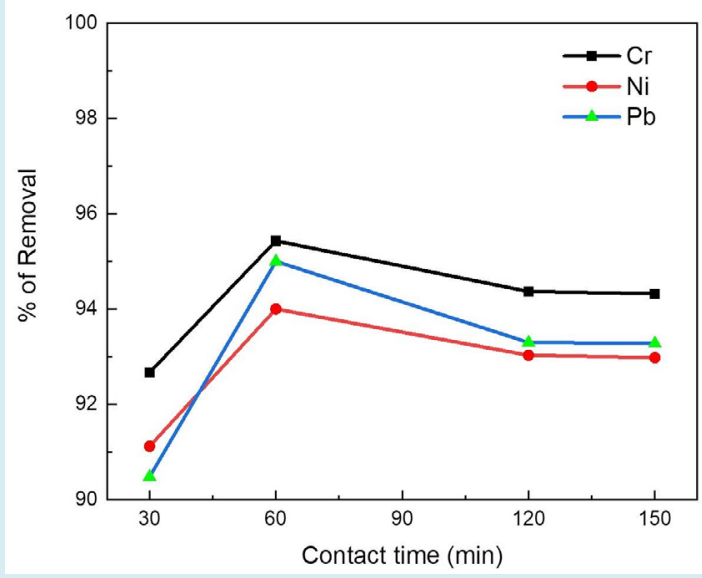

(b)

Figure 1: Effect of contact time on $\mathrm{Cr}, \mathrm{Ni}$ and $\mathrm{Pb}$ removal by spent tea leaves (a) and sawdust (b) adsorbent.

\section{Effect of Adsorbent Dose}

The effect of adsorbent dose was conducted with varying amount of absorbent starting from 1.5 to $17 \mathrm{~g} / \mathrm{L} .250 \mathrm{~mL}$ of sample was treated with different number of doses of spent tea leaves and sawdust adsorbent. The effect of adsorbent dosage on the amount of the metal ions adsorbed shown in Figure 2. 


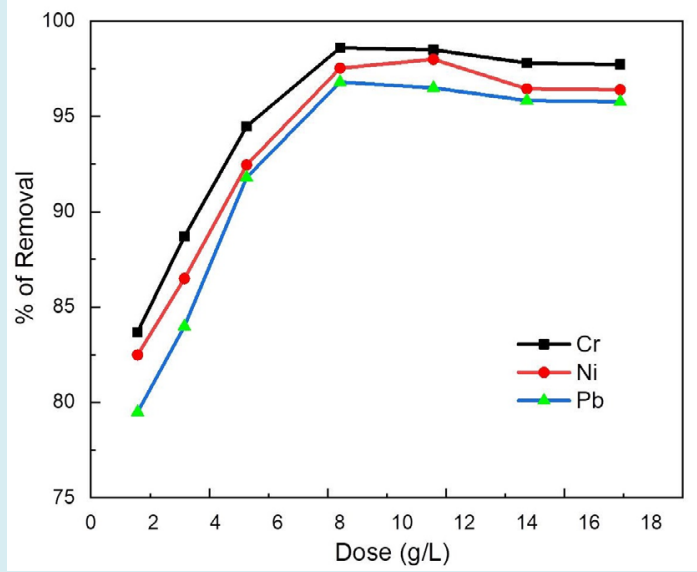

(a)

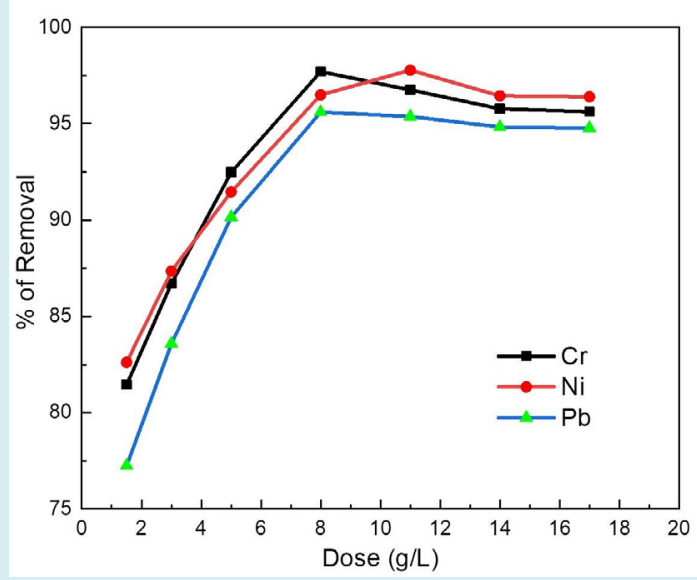

(b)

Figure 2: Effect of adsorbent dose on $\mathrm{Cr}, \mathrm{Ni}$ and $\mathrm{Pb}$ removal by spent tea leaves (a) and sawdust (b) adsorbent.

The percentage of heavy metals removal is seen to increase with adsorbent dose up to $8 \mathrm{~g} / \mathrm{L}$ for both samples. After that dose, very negligible uptake was happened.

\section{Effect of pH}

pH effect was performed taking a specific adsorbent dose and contact time. The $\mathrm{pH}$ was varying using dilute $\mathrm{NaOH} / \mathrm{HCL}$ solution. The samples were agitated for specific time, filtered and then analyzed. Figure 3 revealed that the adsorption capacity of the metal ions by spent tea leaves is higher than that of sawdust, which is clearly affected by the $\mathrm{pH}$. The dependence of metal uptake on $\mathrm{pH}$ related to the functional groups of the adsorbent and the solution chemistry [21]. The minimal adsorption at low $\mathrm{pH}$ may be due to the higher concentrations and high mobility of protons, which worked as a competitor and preferentially adsorbed rather than the metal ions on the active binding sites [22].

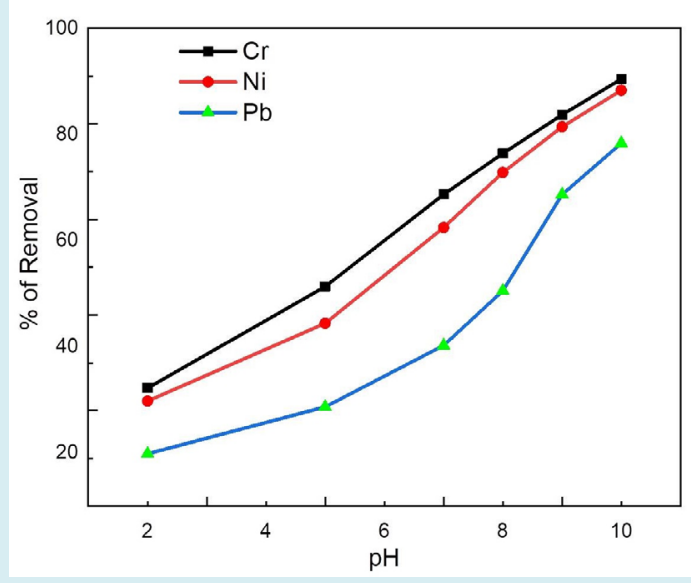

(a)

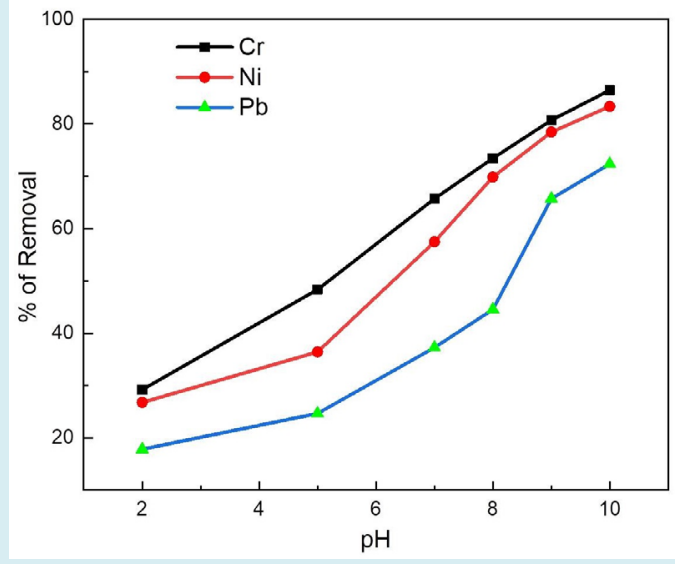

(b)

Figure 3: Effect of $\mathrm{pH}$ on $\mathrm{Cr}, \mathrm{Ni}$ and $\mathrm{Pb}$ removal by spent tea leaves (a) and sawdust (b) adsorbent. 


\section{Comparison between Percentage of Removal}

The comparison of percentage of heavy metals removal from tannery wastewater using sawdust and sent tea leaves as adsorbent is shown in Figure 4.
For all the heavy metals removal from tannery wastewater, spent tea leaves as adsorbent shows the relatively better removal percentage than the sawdust.

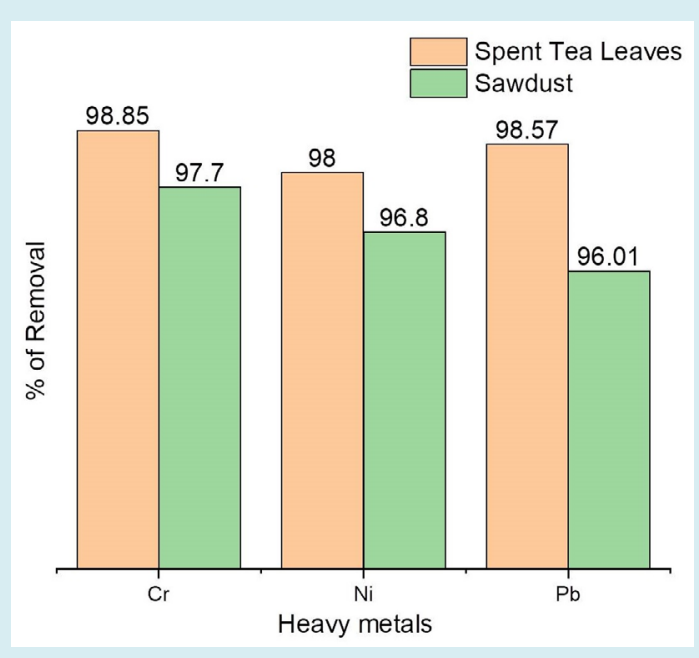

Figure 4: \% of removal ( $\mathrm{Cr}, \mathrm{Ni} \& \mathrm{~Pb}$ ) by spent tea leaves and sawdust adsorbent.

\section{Scanning Electron Microscope (SEM)}

The SEM image is shown in the following Figure 5. Based on the surface of SEM image, spent tea leave has porous structure and sawdust has smooth surface areas with long ridges.

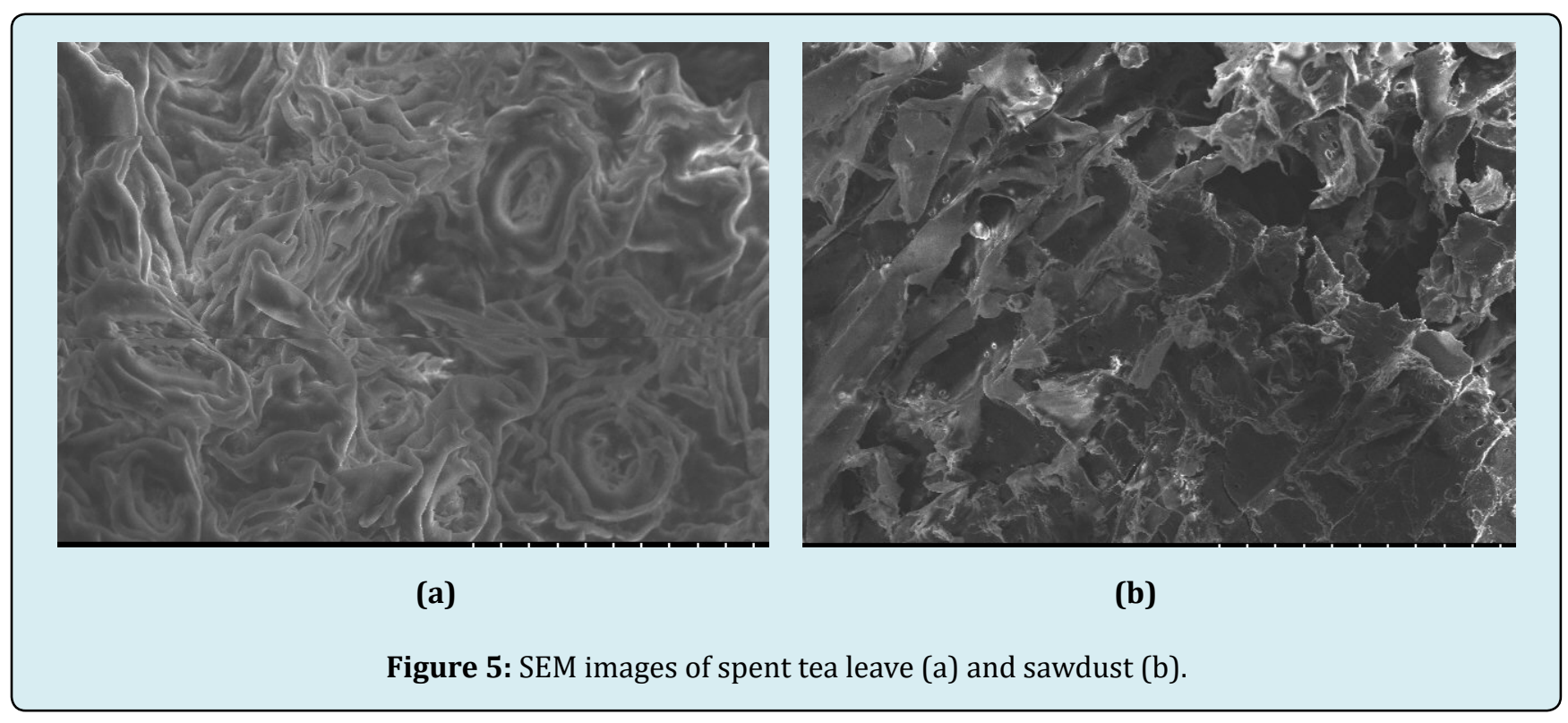

\section{Adsorption Isotherms}

Adsorption isotherm is an equilibrium plot of the solid phase $\left(\mathrm{q}_{\mathrm{e}}\right)$ versus liquid phase concentration $\left(\mathrm{C}_{\mathrm{e}}\right)$ at fixed temperature. Freundlich and Langmuir's isotherms are the simplest known relationships which describe the adsorption equation [23]. Freundlich and Langmuir adsorption isotherm parameters of spent tea leaves and sawdust are shown in Figure 6. The regression coefficient of Freundlich and Langmuir's isotherms of spent tea leaves and sawdust are close to each other and which are more than 0.9. Both Langmuir and Freundlich isotherms are followed by the 
adsorptions which indicate the formation of a monolayer of adsorbate on the outer surface of the adsorbent and the heterogeneity of the adsorbent.
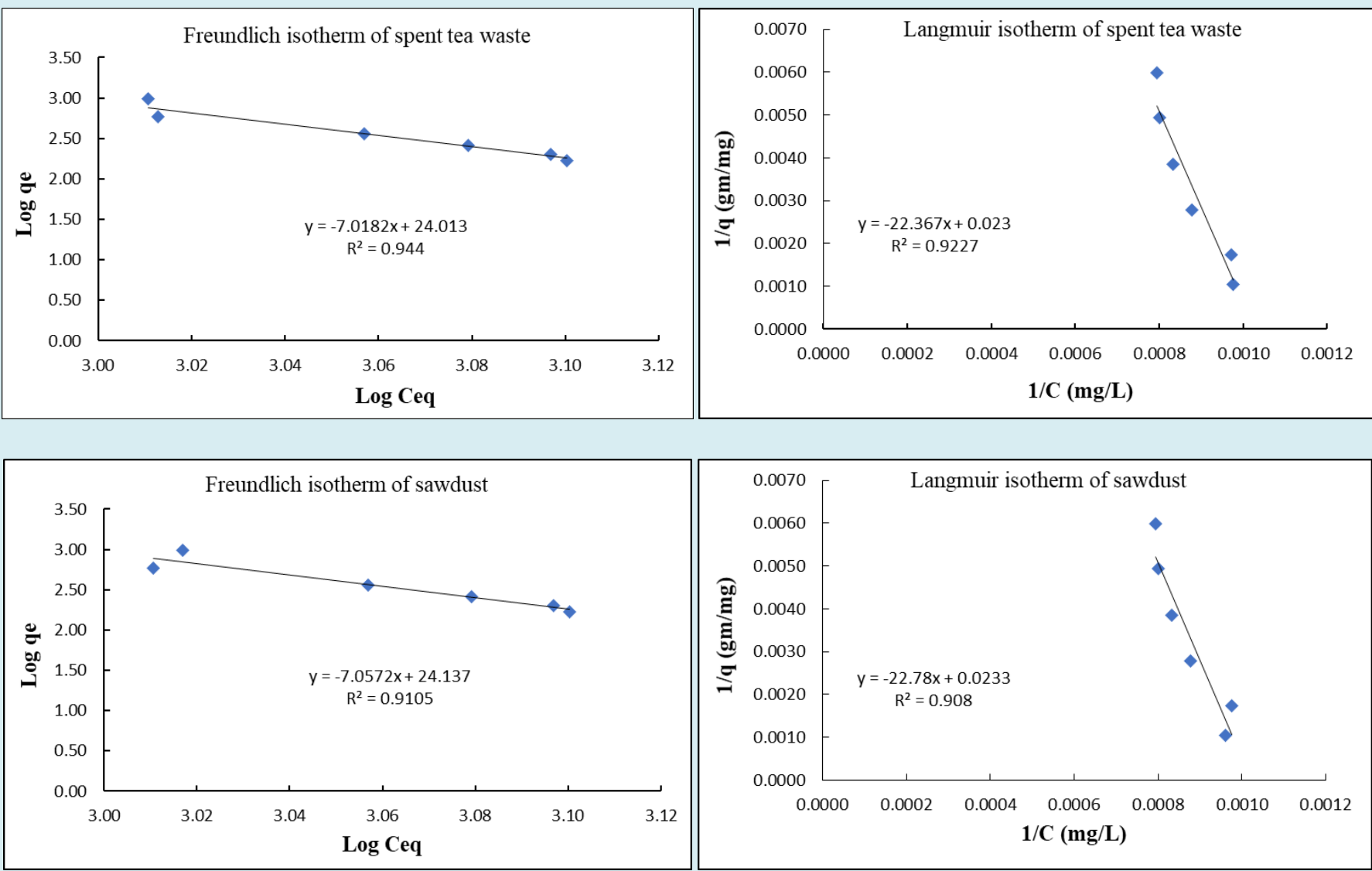

Figure 6: Adsorption Isotherms of spent tea leaves and sawdust adsorbent.

\section{Conclusion}

Tannery effluents are not suitable for discharging into surface water bodies directly which pose potential threats to human health as well as to the environment. This study revealed that the spent tea leaves as well as sawdust using as adsorbent could reduce certain pollution levels of heavy metals like $\mathrm{Cr}, \mathrm{Ni}$ and $\mathrm{Pb}$ from tannery wastewater. The adsorption can be influenced by several factors, such as, adsorbent mass, contact time, $\mathrm{pH}$ etc. Hence, there is a need to optimize these factors to maximize the treatment efficiency of adsorbents and minimize the treatment cost for tannery wastewater.

\section{Data Availability}

All information about the conducted research is available from the corresponding author, e-mail: emsayid@gmail.com.

\section{Acknowledgements}

The authors are thankful to the Centre for Advanced Research in Sciences (CARS), University of Dhaka for providing technical facilities of this research.

\section{Conflict of Interest}

On behalf of all authors, the corresponding author states that there is no conflict of interest.

\section{References}

1. Alam MN, Mia MAS, Ahmad F, Rahman MM (2018) Adsorption of chromium (Cr) from tannery wastewater using low cost spent tea leaves adsorbent. Applied Water Science 8: 129.

2. Mia MAS, Alam MN, Ahmad F, Alam MZ, Rahman MM, et al. (2017) Treatment of Tannery wastewater by Electrocoagulation Technology. Journal of Scientific and 
Innovative Research 6(4): 129-134.

3. Dhanakumar S, Solaraj G, Mohanraj R, Pattabhi S (2007) Removal of Cr (VI) from aqueous solution by adsorption using using cooked tea dust. Indian J Sci Technol 1(2): $1-6$.

4. Bhavsar K, Patel P (2014) Efficiency Evaluation of Tea Waste for Adsorption of Hexavalent Chromium from Industrial Effluent. Int J Sci Res 3(7): 2319-7064.

5. Amarasinghe BMWPK, Williams RA (2007) Tea waste as a low-cost adsorbent for the removal of $\mathrm{Cu}$ and $\mathrm{Pb}$ from wastewater. Chem Eng J 132(1-3): 299-309.

6. Gopalakrishnan S, Kannadasan T, Velmurugan S, Muthu S, VKP (2013) Biosorption of Chromium (VI) from Industrial Effluent using Neem Leaf Adsorbent. Res J Chem Sci 3(4): 48-53.

7. Ahluwalia SS, Goyal D (2005) Removal of heavy metals by waste tea leaves from aqueous solution Eng Life Sci 5(2): 158-162.

8. Aikpokpodion PE, Ipinmoroti RR, Omotoso SM (2010) Biosorption of Nickel (II) from Aqueous Solution Using Waste Tea (Camella cinencis) Materials. Am J Toxicol Sci 2(2): 72-82.

9. Manish R, Prashant D, Pawan L, Shyam S, Vasant M (2013) Low cost-efficient treatment for contaminated water. $13^{\text {th }}($ Edn.), World Wide Workshop for Young Environmental Scientists (WWW-YES-2013)-Urban waters: resource or risks?, France.

10. Mahvi AH, Naghipour D, Vaezi F, Nazmara S (2005) Teawaste as An Adsorbent for Heavy Metal Removal from Industrial Wastewaters. Am J Appl Sci 2(1): 372375 .

11. Kadirvelu K, Thamaraiselvi K, Namasivayam C (2001) Removal of heavy metal from industrial wastewaters by adsorption onto activated carbon prepared from an agricultural solid waste. Bioresour Technol 76: 63-65.

12. Williams CJ, Aderhold D, Edyvean GJ (1998) Comparison between biosorbents for the removal of metal ions from aqueous solutions. Water Res 32: 216-224.
13. Argun ME, Dursun S, Ozdemir C, Karatas M (2007) Heavy metal adsorption by modified oak sawdust: Thermodynamics and kinetics. J Hazard Mater 141: 7785.

14. Emongor V, Nkegbe E, Kealotswe B, KoorapetseI, Sankwasa S, et al. (2005) Pollution Indicators in Gaborone Industrial Effluent. J Appl Sci 5(1): 147-150.

15. Hasan SH, Singh KK, Prakash O, Talat M, Ho YS (2008) Removal of $\mathrm{Cr}$ (VI) from aqueous solutions using agricultural waste maize bran. Journal of Hazardous Materials 152: 356-365.

16. Khattri S, Singh MK (2009) Removal of malachite green from dye wastewater using neem sawdust by adsorption. J Hazard Mater 167(1-3): 1089-1094.

17. Helgilibrary (2013) Tea Consumption Per Capita in Bangladesh.

18. Boonamnuayvitaya V, Chaiya C, Tanthapanichakoon W, Jarudilokkul S (2004) Removal of Heavy metals by adsorbent prepared from pyrolyzed coffee residues and clay. Sep Purif Technol 35(1): 11-22.

19. Shunli Wan, Zhaozhao Ma, Yao Xue, Minghai Ma, Shengyou Xu (2014) Sorption of lead (II), cadmium (II) and copper (II) ions from aqueous solutions using tea waste. Ind Eng Chem Res 53(9): 3629-3635.

20. Bhavsa K, Patel P (2014) Efficiency evaluation of tea waste for adsorption of hexavalent chromium from industrial effluent. Int J Sci Res 3(7): 2319-7064.

21. Dhabab JM (2011) Removal of some heavy metal ions from their aqueous Solutions by duckweed. Journal of Toxicology and Environmental Health Sciences 3(6): 164-170.

22. Amer $H$ (2015) Removal of Lead from Industrial Wastewater using a Low Cost Waste Material. The American University in Cairo.

23. Kaakani MW (2012) Heavy Metal Removal From Wastewater Using Novel Adsorbent. American University of Sharjah, UAE. 